mittee of the Medical Research Council since its inception and its chairman for many years. $\mathrm{He}$ contributed in this and other ways to the improvement of health through better nutrition. As a member of the Scientific Food Policy Committee of the War Cabinet and later of the Chief Medical Officer's Cormmittee of the Ministry of Health, he exercised a powerful influence on the medical aspects of food policy in Great Britain. As chairman of the Food Rationing (Special Diets) Advisory Committee he took an important part in the difficult task of deciding how war-time rations should be modified or supplemented for persons with certain diseases.

Research abroad owes much to his influence, and in recent years he visited Africa, India, Australia and New Zealand for the express purpose of advising on research. Earlier he had been to Canada and on other occasions to the United States. In all these countries he had many friends. He took an active interest in the work of the British Council and was chairman of the advisory Medical Panel from its formation in 1942, and he gave unstinting help and encouragement to the Council's medical work; his interest in the British Medical Bulletin never flagged, and it was his abiding concern to ensure that this journal conformed to its main purpose of presenting to overseas readers the many aspects of medical research in which British workers have excelled. For many years he was active in the development of medical research in Colonial territories and was chairman of the Colonial Medical Research Committee. Not only did he recognize the great need for the application of medical science, but he also foresaw what has only recently been widely recognized as a major problem, namely, the need for relating the rapidly increasing population to the supply of sufficient food. $\mathrm{He}$ insisted that "most of the political, social and economic difficulties in tropical countries are, and will continue to be, biological in nature, and the sooner this fact is recognized the sooner will these difficulties be controlled or dispersed ... and we can only pray," he said, "that there is sufficient wisdom left among us to use the fruits of science properly"?

Those who have known Sir Edward Mellanby and his work can easily add further tributes from their knowledge of other contributions of this great man to the quantity and quality of the life and living of mankind. The illustrations given speak, out of his own mind, of the man, his work, character, ideals and objectives in ways which need no elucidation; indeed, any attempt to do so would be unjustifiable presumption. It is a sign of his influence and calibre that those who knew him best are united in their profound respect and affection for him. Our appreciation of the contribution of his constant partner, Lady Mellanby, must be one of gratitude; and we trust that she, with us, will find comfort in contemplation of his magnificent record of achievement.

\section{B. S. Platt}

${ }^{1}$ Mellanby, E., The Hopkins Memorial Lecture, J. Chem. Soc., 713

(May 1948).
2 Medical Research Council Minute, February 18, 1955.

3 Lancet, p. 309 (February 5, 1955).

- Mellanby, E., The Harveian Oration, Lancet, ii, 929 (1939).

5 Mellanby, E., The Huxley Lecture, pp. 12 and 7 (1935).

- Medical Research Council Report 1945-8, p. 37.

Mellanby, E., Rede Lecture, pp. 5, 62 and 59 (Camb. Univ. Press, 1939 ).

8 Mellanby, E., 13th Stephen Paget Memorial Lecture, "The Fight Against Disease", 27, pp. 5, 4, 2 (1939)

- Mellanby, E., Quart. J. Med., 9 , No. 35 (1916).

30 Mellanby, E., "A Story of Nutritional Research", pp. 430 and 431 (Williams and Hopkins, Baltimore, 1950).

11 Mellanby, E., "Brit. Med. J., ii, 863 (1951).
"2 Mellanby, E., "Nutrition and Disease" (Oliver and Boyd, Edinburgh, 1934).

\section{Prof. J. K. Parnas}

News has been received recently of the death of J. K. Parnas, formerly professor of physiological chemistry in the University of Lwów (Lemberg), known internationally for his fundamental researches in the biochemistry of muscle.

Jakób Karol Parnas was born in Eastern Poland on January 17, 1884, and as a boy was educated in Lwów. He then entered upon an academic career as a student of chemistry, at the Technische Hochschule of Berlin-Charlottenburg. In 1905 he joined the laboratory of Richard Willstätter in Zurich, where as a subject for his Ph.D. dissertation he was allotted the tedious task of preparing the so-called third (or 'amphi') naphthoquinone. It was much to the pupil's credit, and to his teacher's delight, when two years later, after numerous trials with a wide range of metallic oxides, he succeeded in preparing the crystals of this long-sought-after labile compound. Years later this achievement brought him warm praise from Willstätter, who in his autobiography records also the accident which occurred in the course of Parnas's experiments, when a preparation of gold oxide freshly removed from the desiccator exploded in contact with a spatula, and countless particles of gold became lodged in the young experimenter's eye. Although some of the larger particles were removed surgically, smaller ones stayed in the cornea permanently, fortunately without discomfort to the bearer, who in his later years was ever ready to exhibit them to his students and accompany this with a suitable reference to the physiological inertness of gold as a 'noble' metal.

Having thus obtained his doctorate, Parnas removed to Hofmeister's laboratory in Strassburg, where he worked until the outbreak of war in 1914, except for short periods spent on research at the Stazione Zoologica in Naples and in the Physiological Laboratory in Cambridge. The years which he spent with Hofmeister, first as 'assistant' and later as 'dozent', remained in Parmas's memory as his happiest ones, and for Hofmeister himself he preserved lasting devotion and admiration. His first scientific contribution from this laboratory, which he submitted to the Biochemische Zeitschrift in 1906, was on the purification, properties and composition of brain cephelin, a subject of which he was very fond but on which he worked only for a few more years.

Soon afterwards, Parnas's interest turned to the intermediary metabolism of animal tissues-more specifically, the physiological significance of the Cannizaro reaction. In 1910 he demonstrated that this reaction, in which two molecules of aldehyde interact to produce one molecule of acid and one of alcohol, is catalysed in the liver by a soluble enzyme which he named 'aldehyde mutase'. The study of this enzyme formed an introduction to Parnas's further work on enzymic processes underlying the intermediary carbohydrate metabolism of tissues, particularly that of muscles. Among his other contributions made at Strassburg, three deserve specific mention: (i) the recognition of the fact that of the two optical isomers of lactic acid, one, namely, $x(+)$ lactic acid, is metabolized in the animal body in preference to the $\mathbf{D}(-)$ isomer; (ii) the elaboration of energy requirements for smooth and skeletal muscles, both when resting and during contraction; and (iii) a quantitative study-one of the earliest of its kind-of the relationship between the disappearance of glycogen and the formation of lactic acid in isolated, contracting frog muscles. In the last- 
mentioned study, Parnas carried out his experiments partly in collaboration with Richard Wagner; their two names are also linked with the design, a few years later, of the Parnas-Wagner distillation apparatus for the micro-determination of nitrogen.

After the First World War, Parnas returned to his native country and resumed with great vigour his research activities, at first for a short time in Warsaw, and later at the Joannes-Casimirus University in Lwów, where within a few years he succeeded in creating a flourishing centre of teaching and research and in assembling around him a group of devoted and enthusiastic co-workers, often referred to as the 'Parnas School'. Of these, J. Heller (now professor of biochemistry in Warsaw) and W. Mozolowski (now occupying the chair of biochemistry in Gdansk) shared with Parnas the credit for the discovery of the process of ammonia formation in blood (1924) and in muscle (1927), and for establishing that this ammoniogenesis is due to the deamination of adenylic acid to inosinic acid. Further intense research on the significance of this process in muscular contraction was greatly facilitated by the method for large-scale preparation of adenylic acid developed in Parnas's laboratory in 1932 by his pupil and co-worker, Paul Ostern (who died tragically during the Second World War).

The Parnas reaction, discovered in 1934, estab. lished that adenosine triphosphate, the mothersubstance of adenylic acid, is directly involved in the enzymic transfer of phosphate groups, from the phosphorylated intermediary products of muscle glycogenolysis, to creatine. This finding, coupled with the Lohmann reaction, formed the basis of much of the later work on the 'chemical linkage' processes, not only in the muscle but also in all other animal tissues, as well as in yeast and bacteria. The 1930 's were probably the most active period in Parnas's life. Those who, like myself, had the good fortune to be associated with him in that phase of his activity, will remain filled with admiration for his qualities of leadership, his profound knowledge of chemistry and physiology, his exceptional skill in designing experiments, and last but not least, his almost uncanny encyclopædic memory. This great gift enabled Parnas to master several languages, to retain faultessily the names and faces of countless students, to quote page-long excerpts of Greek and Latin poetry, which he learnt as a boy, and to shower upon his pupils scientific facts and chemical formulæ.

As a teacher, Parnas was most stimulating, and his text-book of biochemistry, written in Polish, is a masterpiece. Sometimes, carried away by his enthusiasm while lecturing, in exposing the intricate mechanisms of chemical reactions (which he invariably illustrated by the most complicated and ingenious demonstrations), he would forget completely that but few in his student audience were capable of following him. A man of exceptionally powerful physique, he used to amuse the medical students by pointing out that there are no data in the existing tables for computing the basal metabolism of a person of his size and weight. Yet, this massive frame did not prevent him from constructing and handling the most delicate instruments and apparatus.

Parnas's many friends in Britain and elsewhere will mourn the passing of this exceptional man.

T. ManN

\section{NEW FELLOWS OF THE ROYAL SOCIETY}

A T the meeting of the Royal Society on March 17, the following were elected to fellowship :

Prof. D. R. BAtes, professor of applied mathematics, The Queen's University, Belfast, distinguished for his contributions to theoretical atomic physics and its application to the interpretation of phenomena in the earth's atmosphere.

E. J. H. CoRNER, lecturer in botany, University of Cambridge, distinguished for his researches on fungi and on tropical floras.

Prof. A. H. Cotrrell, professor of physical metallurgy, University of Birmingham, distinguished for his research work, both theoretical and practical, concerning the mechanical properties of metals.

Prof. S. Devons, professor of physics, Imperial College of Science and Technology, University of London, distinguished for his researches in nuclear physics, including the investigation of short-lived states of nuclei.

Prof. A. W. DownIe, professor of bacteriology, University of Liverpool, distinguished for his contributions to bacteriology and virology and especially into the viruses belonging to the pox group.

Prof. K. C. Dunham, professor of geology, University of Durham, distinguished for his petrological researches, his work on the genesis of ore deposits, and on the stratigraphy of the north of England.
Dr. D. J. FinNey, reader in statistics, University of Aberdeen, and director of the Agricultural Research Council's Unit of Statistics, distinguished for his work in the development and application of statistics to biological problems, especially in the field of bioassay.

Dr. A. FLECK, chairman, Imperial Chemical Industries, Ltd., distinguished for his contributions to chemical technology and for his pioneering work on the radioactive elements.

Prof. K. J. FrankLIN, professor of physiology, St. Bartholomew's Hospital Medical College, London, distinguished for the application of X-ray cinematography to physiological problems, for work on veins and vascular reflexes, and the history of physiology.

Prof. W. P. Hawthorne, professor of thermodynamics, University of Cambridge, distinguished for his researches in the combination of thermodynamics and hydrodynamics on which the design of highspeed heat engines is based.

Prof. D. H. Hey, Daniell professor of chemistry, King's College, University of London, distinguished for his original contributions to the study of free radicals of short life as intermediates in chemical reactions, and to synthetical organic chemistry.

Sir Harold Himsworth, secretary of the Medical Research Council, distinguished for his contributions to clinical investigation, and especially for researches 